\title{
Analysis of Gender and Governance of Value Chain-Based Systems on Rice and Vegetable Crops in Southern Benin and Mali
}

\author{
Sounkoura Adétonah ${ }^{1}$, Ousmane Coulibaly¹, Remy Ahoyo ${ }^{1}$, Eric Sessou1, Urbain Dembélé2, \\ Joel Huat ${ }^{3,4}$, Gladys Houssou' ${ }^{1}$, Gbelidji Vodouhe', Julie Loko ${ }^{1}$ \\ ${ }^{1}$ International Institute of Tropical Agriculture, Cotonou, Benin \\ ${ }^{2}$ Institute of Rural Economy, ESPGRN/CRRA-Sikasso, Sikasso, Mali \\ ${ }^{3}$ Rice Center for Africa, AfricaRice, Cotonou, Benin \\ ${ }^{4}$ CIRAD, UPR Hortsys, Montpellier, France \\ Email: s.adetonah@cgiar.org
}

Received 31 March 2015; accepted 14 June 2015; published 17 June 2015

Copyright (C) 2015 by authors and Scientific Research Publishing Inc.

This work is licensed under the Creative Commons Attribution International License (CC BY).

http://creativecommons.org/licenses/by/4.0/

(c) (i) Open Access

\section{Abstract}

This present study analyses gender and governance in the rice and vegetable-based value chain systems in 3 lowlands of southern Benin and 2 lowlands in Southern Mali. A sample of 243 farmers, 1 modern processing unit, 18 traditional processors, 76 traders and 8 national institutions were interviewed in Benin and Mali. Descriptive statistics and Harvard analytical framework were used for the analysis of governance and gender respectively in the value chains. The majority of farmers have access to the use of land. Women produce up to $80 \%$ of basic foods for household consumption and sale. However they don't have the control of these resources (capital and land). Decision making in relation to resources (land, water labor, credit) is under the control of men and natives. The governance analysis showed that the products of lowlands are not subject to quality control, with no public inspection for health and product quality. There is no input subsidy for actors in both countries. There are informal contracts between actors of the rice based systems in Mali and Benin. The markets are open for all the products and credit systems do exist. Some structures are involved in upstream and downstream chain components for training in various activities.

\section{Keywords}

Value Chain, Gender, Governance, Benin, Mali 


\section{Introduction}

In Sub-Saharan Africa, lowlands valleys are valuable resources for increasing production and incomes of farmers and other actors. The development of lowlands, through the intensification of rice and vegetable crops systems will increase productivity and incomes. Thus, rice and vegetable crops production can be attractive value chain development opportunities for smallholder producers. The value chain analysis can show linkages among production, transportation, processing and marketing of agricultural products. Understanding value chain governance and how it is organized and coordinated can enhance the profitability at all segments of the value chains [1]. Improving the coordination of the different actors in the chain reduces transaction costs, helps to ensure the quality and safety of products, and stimulates the development of marketing strategies [2].

Gender studies and agriculture policies have shown that the integration of gender in agricultural value chains provide efficient use of resources and better livelihoods for rural women, children and men [3]. The gender approach into value chain allows men and women to have fairly equal opportunities to participate in the development activities and benefits (Hafkin, op, city). The overall objective of this study is to analyze the performance of lowland value chain systems through gender and governance.

\section{Methodology and Data}

\subsection{Harvard Framework}

In this study, the analytical framework of Harvard (Figure 1) is used in various stages of planning to analyze disaggregated information's by cultural, socio-cultural and economic classes, including gender.

The framework or matrix of Harvard is a set of tools to collect and analyze information on the roles of women and men in the community and to take into account these roles in the planning of projects development. This framework has four components:

- The profile of activity: It shows who is doing what, throughout the chain by decomposing the information by gender and socio-cultural group. It shows what type of actors is responsible for such activity. The description of these activities must indicate when there is labor deficit and labor abundance, therefore an appropriate change analysis may be done in term of: Who and what will be affected? Who need capacity building?

-The access to and control of resources: It shows who has access to and control of resources needed to achieve the identified activities. The resources include land, equipment, animals for traction, inputs, family labor, services such as - credit, information, etc.

-The profile influences factors: It identifies the external constraints that may influence the chain and helps to identify intervention strategies in valuing assets.

- Analysis of the project cycle: The project cycle is the continuous process in which every step is necessary to ensure the viability and success of the project and determine the next step depends on the previous results.

\subsection{Data Collection}

The study was conducted in the departments of Mono and Couffo in southern Benin and the Sikasso region of southern Mali, targeting lowland areas such as Doumanaba and Zangaradougou in Mali, and Vovokanme, Agbédranfo and Houinga-Houégbé in Benin (Figure 2).

A total of 243 farmers have been selected on the basis of 123 producers in Benin and 120 producers in Mali. One processing unit is surveyed in Benin and 18 processors in Mali. As for traders, 60 have been interviewed in Benin and 16 in Mali. At the meso level, eight (8) structures are investigated in Benin and Mali.

Both quantitative and qualitative data have been used to analyse the collected data. The data are processed and analyzed using the Statistical Package of Social Sciences software (SPSS Version 16). Descriptive statistics are used to generate averages, frequencies, standard deviations and double entry tables. The Harvard Analytical Framework is used to analyze the gender issues in terms of the activity patterns, access to and control over productive resources for men, women, youth, indigenous and non-indigenous.

\section{Results}

\subsection{Gender Analysis in the Lowlands Value Chain in Benin and Mali}

Access to a resource is the ability to use this resource whilst resource control refer to the decision power over 


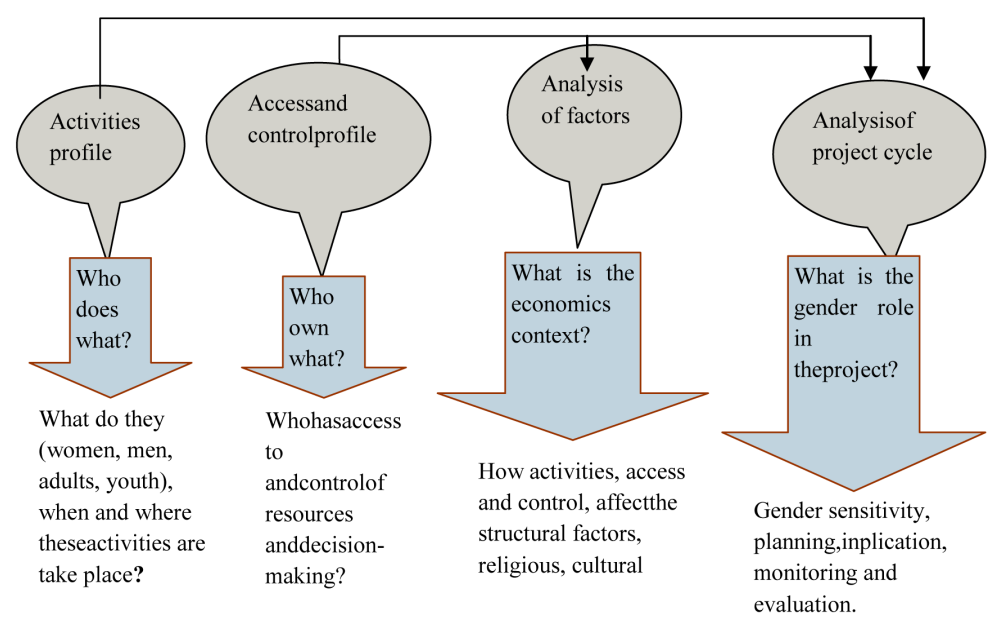

Figure 1. Harvard analytical framework.

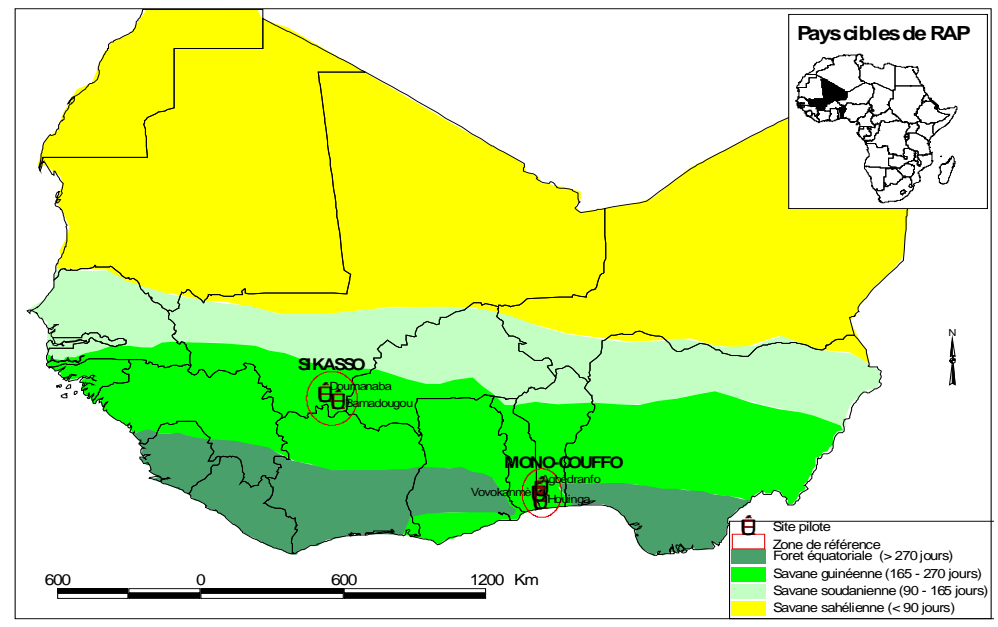

Figure 2. Project areas in Benin and Mali.

this resource. In Benin and Mali, men and women have different access and control of productive resources (land, agricultural inputs, labor, and agricultural credit). However, the process of decision-making on these resources within household is dominated by men who have easier access to training, to the family labor and education.

Figure 3 and Figure 4 show the control of productive resources by lowlands actors in Benin and Mali.

Table 1 summarizes the resource access profile in the shallows by men and women, indigenous and non-indigenous to Benin and Mali

The analysis of the agricultural calendar for rice cultivation in Benin show that asks that take much longer as bird hunting and are most difficult are exercised exclusively by women and children as shown in Table 2.

\subsection{Analysis of Governance in the Value Chain: Regulations, Standards and Labeling}

The standards are guidelines defining and controlling product quality characteristics. They consider the intrinsic attributes and ethical quality. Business relationships in the value chain and should observe standards of product safety and quality standards and environmental and social standards there or applicable.

Products from the shallows in Benin and Mali are not subject to quality control. The different actors in the value chain are neither trained nor informed about the norms and standards of quality. They face no control that can compel them to ensure little time is the quality of deliverables. However, in Benin, the Plant Protection 


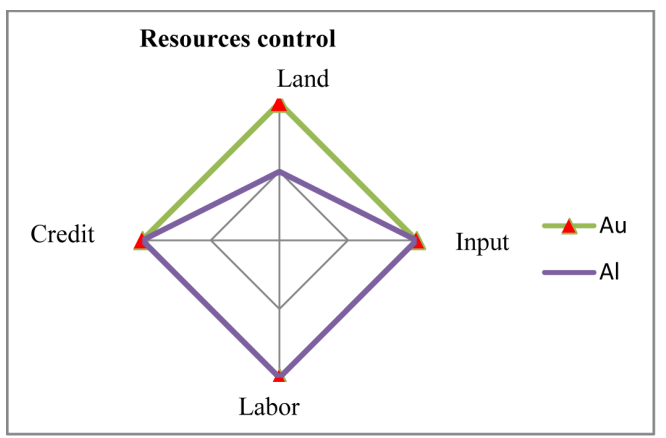

(a)

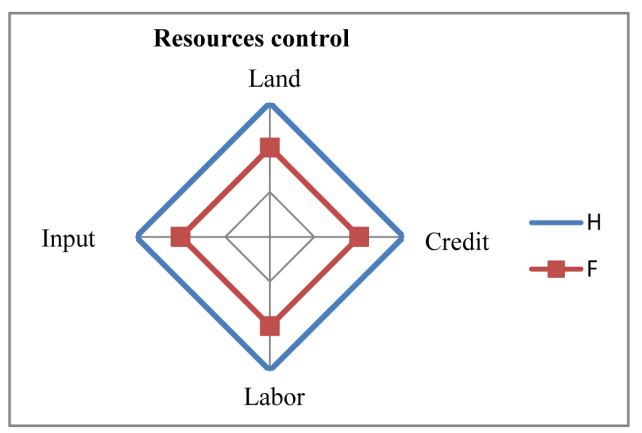

(b)

\section{Figure 3. Control of resources in Benin.}

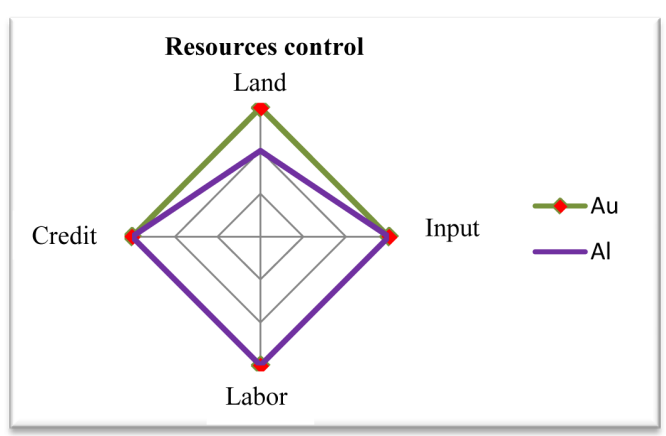

(a)

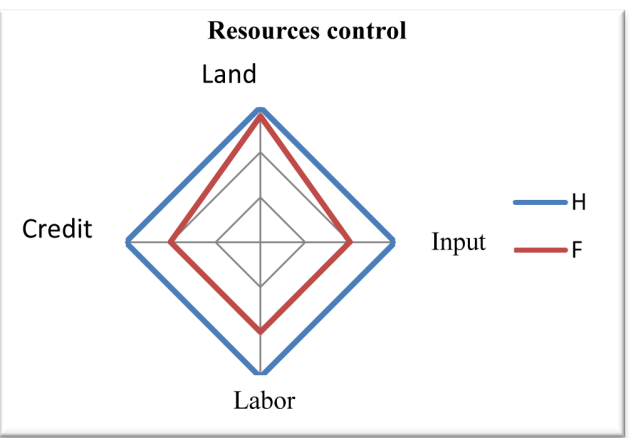

(b)

Figure 4. Control of resources in Mali.

Table 1. Profile of access to resources such as the Benin and Mali.

\begin{tabular}{|c|c|c|c|c|c|c|c|c|}
\hline \multirow{2}{*}{ Resources } & \multicolumn{4}{|c|}{ Benin } & \multicolumn{4}{|c|}{ Mali } \\
\hline & H & $\mathbf{F}$ & Au & Al & H & $\mathbf{F}$ & Au & Al \\
\hline Agricultural land & $\mathrm{xx}$ & $\mathrm{xx}$ & $\mathrm{xx}$ & $\mathrm{Xx}$ & $\mathrm{xx}$ & $\mathrm{xx}$ & $\mathrm{xx}$ & $\mathrm{xx}$ \\
\hline Agricultural inputs & $\mathrm{xx}$ & $\mathrm{xx}$ & $\mathrm{xx}$ & $\mathrm{xx}$ & $\mathrm{xxx}$ & $\mathrm{XxX}$ & $\mathrm{xxx}$ & $\mathrm{xxx}$ \\
\hline Labor & $\mathrm{xxx}$ & $\mathrm{X}$ & $\mathrm{xx}$ & $\mathrm{XX}$ & $\mathrm{xxx}$ & $\mathrm{xxx}$ & $\mathrm{Xxx}$ & $\mathrm{XXX}$ \\
\hline Farm credit & $\mathrm{xx}$ & $\mathrm{xxx}$ & $\mathrm{xx}$ & $\mathrm{Xx}$ & $\mathrm{xxx}$ & $\mathrm{xxx}$ & $\mathrm{xxx}$ & $\mathrm{xxx}$ \\
\hline
\end{tabular}

$\mathrm{H}=$ Male; $\mathrm{F}=$ Female. $\mathrm{Au}=$ indigenous. $\mathrm{Al}=$ non-indigenous. $\mathrm{x}$ : Low. $\mathrm{xx}$ : Medium. $\mathrm{xxx}$ : High

Service (SPV) of the Communal Centre for Agricultural Promotion (CeCPA) shall monitor the quality of the crop at the producer level. Indeed, $32 \%$ of producers reported receiving an inspection team to control the quality of their products.

\subsection{Taxation and Subsidy}

More than 95\% of producers and traders surveyed in Benin and Mali have no information about the inputs subsidy (fertilizers, insecticides, herbicides.) for production. The majority of production inputs are inputs used for the cultivation of cotton.

There are taxes on products sold in the markets. $44 \%$ and $38 \%$ of farmers surveyed respectively pay taxes on rice and fresh corn. $53 \%$ and $48 \%$ of producers also pay taxes on the fiddle

\subsection{Price Setting}

Selling prices of products from the lowlands are set in three modes in Benin and Mali: 
Table 2. Division of labor by gender.

\begin{tabular}{|c|c|c|c|c|}
\hline Country & Activities & Men & Women & Children \\
\hline \multirow{7}{*}{ Bénin } & Clearing & $\mathrm{xxx}$ & $\mathrm{xxx}$ & $\mathrm{x}$ \\
\hline & Tillage & $\mathrm{xxx}$ & $\mathrm{xxx}$ & - \\
\hline & Sowing/transplanting & $\mathrm{x}$ & $\mathrm{xx}$ & $\mathrm{x}$ \\
\hline & Weeding & $\mathrm{x}$ & $\mathrm{xx}$ & $\mathrm{x}$ \\
\hline & Bird hunting & - & $\mathrm{xxx}$ & $\mathrm{xxx}$ \\
\hline & Harvest/threshing & $\mathrm{xx}$ & $\mathrm{xxx}$ & - \\
\hline & Marketing & $\mathrm{xx}$ & $\mathrm{xxx}$ & - \\
\hline \multirow{7}{*}{ Mali } & Clearing & $\mathrm{xxx}$ & $\mathrm{xxx}$ & $\mathrm{x}$ \\
\hline & Tillage & $\mathrm{xxx}$ & $\mathrm{xx}$ & $\mathrm{x}$ \\
\hline & Sowing/Transplanting & $\mathrm{x}$ & $\mathrm{x}$ & $\mathrm{x}$ \\
\hline & Weeding & $\mathrm{xx}$ & $\mathrm{xx}$ & $\mathrm{x}$ \\
\hline & Spreaders/fertilizer application & $\mathrm{xxx}$ & - & - \\
\hline & Harvest/threshing & $\mathrm{x}$ & $\mathrm{xxx}$ & $\mathrm{x}$ \\
\hline & Marketing & $\mathrm{xx}$ & $\mathrm{xxx}$ & - \\
\hline
\end{tabular}

Source: RAP Bénin-Mali, 2010. x: Low implication, xx: Medium implication, xxx: High implication.

- Price fixing by producers: producers set their own selling prices of their products based on the price of products on the market and depending on the availability of products on different sales markets. Against in season or high demand, producers have the power to impose on prices.

- Price-fixing by buyers: Customers set the price of products. Rice mainly to Houinga Benin, and NGO called ODIB buy in batches to producers stocks of paddy rice. She fixed the purchase price of which varies 100110FCFA (US 2) per kilogram of rice. For fiddle and eggplant this method of pricing is also observed. So they are selling their products by selling them at prices fixed by the buyer.

- Haggling is a form of negotiation, consensus on the price between the seller and the buyer. This method of pricing is the most dominant for all crops in the two countries.

Figure 5 and Figure 6 show respectively the main modes of pricing products lowland Benin and Mali.

\section{Regulation and Stabilization of Markets and Relationships of Trust among Stakeholders in the Chain}

Relations between producers, input suppliers, traders and processors, the existence or not of alternative markets for the sale of products are discussed in this section.

\subsection{Relations between Producers and Suppliers of Inputs (Fertilizer)}

The criteria for selecting input suppliers to producers are mainly related to the price offered and the distance between the point of sale of these inputs production sites in Benin and Mali. Supplier selection also depends on the quality of products and there customer loyalty is almost no contract between the producers and suppliers (79\% of producers said they did not have contracts with suppliers for the production of rice).

However, some producers have oral type contracts with a duration of one year (a crop), often with input suppliers. The credit is provided by the suppliers as loyal customers. Table 3 shows the types of relationships between actors (producers and input suppliers).

\subsection{Relations between Producers and Traders}

The mode of marketing is individual for the majority of producers in Mali and Benin. This method of marketing 


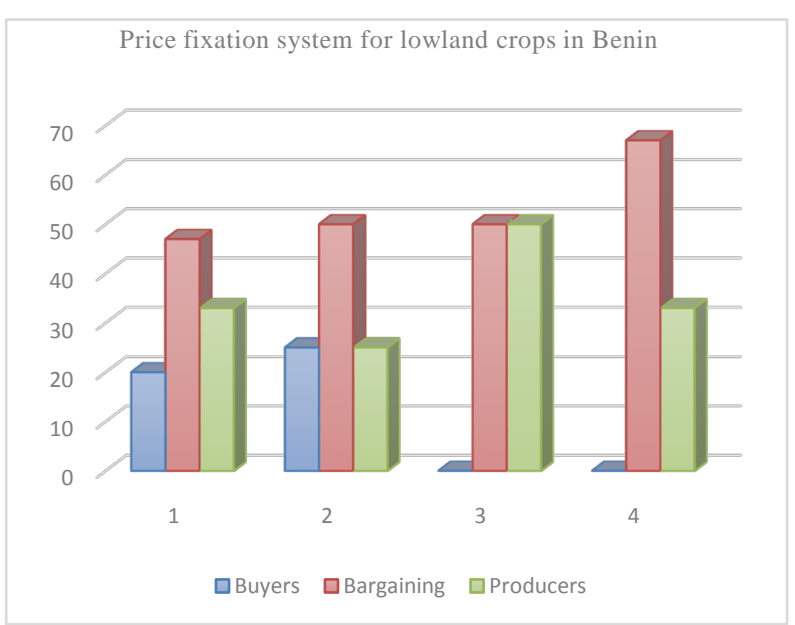

Figure 5. Price fixation systems for lowland crops in Bénin Source: RAP Bénin, 2010.

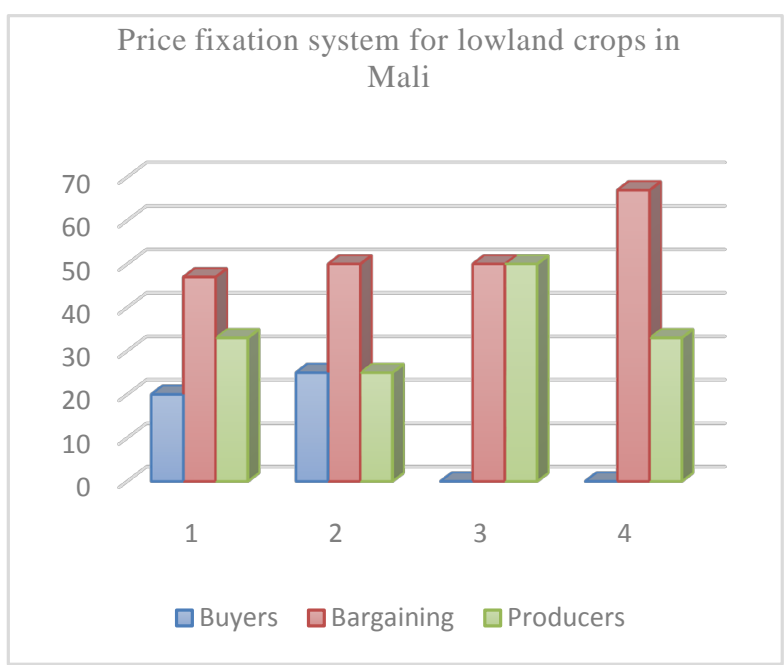

Figure 6. Price fixation system for lowland crops in Mali Source: RAP Mali, 2010.

Table 3. Types of relationships between producers and input suppliers in Benin and Mali.

\begin{tabular}{|c|c|c|c|c|c|c|c|c|}
\hline & & \multicolumn{4}{|c|}{ Bénin } & \multicolumn{3}{|c|}{ Mali } \\
\hline & & Rice & Crincrin & Spinach & Maize & Rice & Potato & Yam \\
\hline \multirow{4}{*}{$\begin{array}{l}\text { Supplier selection } \\
\text { criteria (\%) }\end{array}$} & Price offered & 45 & 49 & 53 & 54 & 32 & 32 & 53 \\
\hline & Quality & 9 & 7 & 8 & 7 & 9 & 20 & 21 \\
\hline & Loyalty & 9 & 5 & 4 & 4 & 7 & 39 & 11 \\
\hline & Proximity & 33 & 36 & 33 & 33 & 50 & 9 & 16 \\
\hline \multicolumn{2}{|c|}{ Sales on credit (\%) } & 30 & 31 & 20 & 17 & 31 & - & - \\
\hline
\end{tabular}

Source: RAP Bénin-Mali, 2010.

is predominant specifically for vegetable crops in Benin and potato in Mali are highly perishable products.

In Benin on site Houinga, rice is sold as paddy and sale is grouped. Indeed, the leaders of the group go in search of customers who buy rice producers. The main customers are the CRR and the NGO ODIB. 
The dominant payment method product is cash sale in Benin and Mali. Table 4 shows the different modes of payment in the shallows in Benin and Mali.

\subsection{Relationships between Producers and Processing Plants}

As before, there is no contract between the producers and the processing unit in Benin and Mali. As soon as the rice is ready for hulling the group leaders call processors for husking rice.

\subsection{Relations between Producers and Others Actors Involved in the Value Chain}

Several actors are involved upstream and downstream of the value chain. Their interventions generally consist of training, or support the various activities of the value chain. For the supply of seeds, PUASA Project (Emergency project for Food Security) through the CeCPA (Regional Center for Agricultural Promotion) gives rice seeds and corn producer groups. Note that these seeds are paid by the PUASA from local seed. PROTOS project provides technical support and participates in the irrigation schemes lowlands through the Regional Union of Farmers of Mono-Couffo (URP/MC). The URP provides supervision of works and coordinates all activities of amenities.

CRR mean while involved in production by granting credit to seed producers. The credit is recovered either in cash or in kind. At the processing level, the RRC has the only processing plant paddy rice husked rice. It is he who is responsible for the rotation in the husking rice producing areas in the departments of Mono and Couffo.

Also note the producers; there are very little formal relations between the structures of interventions. For vegetable crops, only CeCPA involved in the field of production. In Mali, the IER (Institute of Rural Economy) through the DRA (Division of Agricultural Research) works with farmers to improve agricultural production. The NGO AMATEVI (Technical Support to the Mali a Tons Village Association) and the PACR (Project Support to Rural Communities involved in the field of advisory support to farmers' organizations involved in the shallows.

\section{Discussion}

The increase in global demand for food and agricultural products promotes small farmers, particularly women and youth the opportunity to enjoy more market diversification and get a competitive price. In Benin and Mali, men, women, and non-natives have access to productive resources at different levels and modalities. In all the lowlands areas, actors are organized in groups and these groups are accessible to all without distinction. As an active member, the actors have access to the use of productive resources. But when it comes to control and decision making on resources, only native men and women have that power. The process of decision-making is dominated by men who decide which crop to grow, credit demand and labor allocation. The small holders of the lowlands are usually the main actors of the agricultural economy, and mainly engaged in manual labor in rice farming, market gardening and small-scale processing. The low level of literacy, inadequate access to training and market information, policy and regulatory frameworks ignoring gender among the constraints that prevent women from exploiting the full potential of economic opportunities available. Thus, the majority of respondents don't have information on input subsidies. There are no specific inputs for market gardening. The producers then use for rice and vegetable crops NPK and Urea at hat are inputs subsidized by the government. Therefore they have an indirect subsidy from the State through chemical fertilizers and insecticides.

The products of the lowlands are not subject to any control. The CeCPA through sanitary inspection services

Table 4. Payment products in the lowlands.

\begin{tabular}{|c|c|c|c|c|c|c|}
\hline & & Bénin & & & Mali & \\
\hline Payment (\%) & Rice & $\begin{array}{c}\text { Crincrin } \\
\text { (Cloterus olutus) }\end{array}$ & Great nightshade & Rice & Potato & Yam \\
\hline Pre-financing & 0 & 1 & 1 & 5 & 2 & 3 \\
\hline Cash payment & 62 & 91 & 94 & 74 & 30 & 36 \\
\hline Credit sale & 38 & 8 & 5 & 21 & 68 & 61 \\
\hline
\end{tabular}

Source: RAP Bénin-Mali, 2010 
control the quality of harvests in some producers. But the structure doesn't have the skills and resources needed to strict control according to international norms and standards. There is little agreement among stakeholders in the lowlands. Although these contracts exist, they concern only a crop and are in most cases verbal. This explains lack of trust between the actors augments the transaction costs and decreases the net profit level actors. The involvement of support structures (NGOs, program...) and local authorities to establish contract will increase the level of trust between the players and reduce transaction costs.

Rice is the main product manufactured in both countries. Thus in Benin, the shelling is the main form of processing while in Mali steaming is the main form of processing [4]. Vegetable crops do not undergo any transformation and cannot be stored for long. This sometimes requires producers to sell at a low price when supply exceeds demand. Vegetable prices are subject to strong seasonal variations [5]. The selling price increases against season (dry season) due to high demand. Develop short postharvest equipment (storage and processing) would be an opportunity to improve net profits of small producers of lowlands that are dependent on rainfall patterns and influences the supply of vegetables [6].

Sales in both countries are individually. Only the potato is sold collectively sales in Mali but in small proportion to individual sales. During a campaign, rice crops were sold collectively to ADIB NGO Benin. Lowland products do not undergo collective marketing.

\section{Conclusions}

In conclusion, this study showed that the products of the lowlands in Benin and Mali are not subject to rigorous quality control. The actors are neither informed nor trained on the norms and standards of quality. There are no sales contracts or purchases between producers and traders. But with the capacity of producers on the collective marketing of their products, these problems of governance within the actors need to be resolved.

In summary, a significant technical potential exists for the development of rice and other crops grown in the lowlands in Benin and Mali. This potential can be fully realized if the development of production in quantity and quality can attract the investment needed to improve the storage, marketing and product promotion.

\section{Acknowledgements}

We thank all those who contributed to this study and especially the stakeholders working in the lowlands valleys of rice and vegetable. We specially thank the European Union for its financial support to implement of this study.

\section{References}

[1] McCormick, D. and Schmitz, H. (2001) Manual for Value Chain Research on Home Workers in the Garment Industry. Institute of Development Studies, University of Sussex, UK.

[2] Bijman, J. and Oorthuisen, J. (2007) Producers Organizations and Chain Development: Facilitating Trajectories of Change in Developing Countries. Wageningen Academic Publishers, Wageningen.

[3] Hafkin, N. and Hambly, H. (2002) NTIC: l’importance de la question du genre ICT Update Numéro 8: Genre et NTIC $1 \mathrm{p}$.

[4] Dembele, U., Sanogo, F., Coulibaly, S. and Diarra, L. (2010) Rapport d'étude sur le genre, l'équité et la gouvernance dans les chaînes de valeurs cibles dans les bas-fonds de Bamadougou et Doumanaba au Mali. Institut d'Economie Rurale, Bamako, Septembre 2010, 43 p.

[5] Kamdem, D.O. and Mivogo, C.C. (2004) Analyse des filières maraîchères à Yaoundé. Ouvrage IRAD.

[6] Agossou, G., Ahouansou, T., Aly, D. and Assogba-Komlan, F. (2001) Study on the Promotion of the Sector of Vegetable Crops in Benin. Main Report, APR, Benin, 102 p. 